現像液攪汼によって低濃度部の現像の進行が著明となる。 これが所謂カブリの目立った写真になる原因と考えられ る. これは現像液の噴出口の形状，及び位置を検討する ことで改められるすのと考えているが, 早急な改善策と しては現像液の処方を変えることでその目的を達するこ

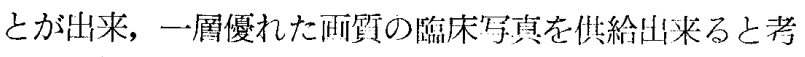
え現在検討中である。

\section{RI によるフィルム事故}

岩手医科大学中央レントゲン部 樋口喜代治・秋津 武志 桜田 俊雄・佐々木 功

\section{[目的]}

診療放射線照射器具, 放射線性同位元素によるフィル ムカブリを経験したので被曝条件による写真濃度との関 係並被曝例について報告する。

被曝条件と写真濃度との関係

ラジウム管並コバルト60管を 4 個の鉛小容器にいれ, そこから $30 \mathrm{~cm}$ へだてたところに6ッ切取枠と線量計を おき均等に被曝されるように配置した，取枠のなかて， $\mathrm{Pb}(0.3 \mathrm{~mm}), \mathrm{FS}, \mathrm{MS}, \mathrm{HS}$ の増感紙を配列し $6 \%$ 切 1 枚のフィルムによる感度比を求めた。被曝量はコロニア ル大型電離槽による積算值によった。

$100 \mathrm{mr}$ 被曝とフィルム濃度 (ベース濃度含まず)

\begin{tabular}{|c|c|c|c|c|c|}
\hline 被曝条件増感紙 & なし & $\mathrm{Pb}$ & FS & MS & HS \\
\hline ラヂウム管一 & 0.27 & 0.47 & 0.71 & 1.05 & 1.77 \\
\hline 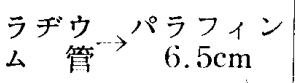 & 0.29 & 0.52 & 0.79 & 1.21 & 1.95 \\
\hline $\mathrm{Co}^{60 \rightarrow} \rightarrow$ & 0.22 & 0.19 & 0.31 & 0.41 & 0.71 \\
\hline 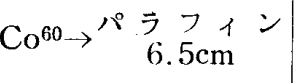 & 0.23 & 0.53 & 0.53 & 1.09 & 1.85 \\
\hline $\begin{array}{l}\mathrm{Co}^{60} 1300 \mathrm{C} \rightarrow \text { パラフ } \\
1 \text { 190度側方政乱 }\end{array}$ & 0.26 & 0.55 & 1.81 & 2.21 & 2.73 \\
\hline
\end{tabular}

\section{〔結果〕}

ラジウムから発する 合としない場合との濃度差は僅少である。C $\mathrm{Co}^{60}$ 汃ら発 する $\gamma$ 線はパラフィン板を透過した場合はしない場合に 比し著るしい濃度の増加をみさらに 90 度側方散乱線のみ の場合はさらに濃度の増加を示す。

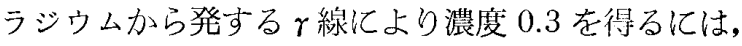
(ベース濃度含まず) 増感紙 HS, $12 \mathrm{mr}$ MS, $24 \mathrm{mr}, \mathrm{FS}$, $40 \mathrm{mr}, \mathrm{Pb}(0.3 \mathrm{~mm}) 60 \mathrm{mr}$, し, $112 \mathrm{mr}$ の線量である.

\section{被曝の実例}

1）胸部撮影（約60秒）左下肺野にカブリ，原因，肺 癌治療の目似で左䏩腔部に $84 \mathrm{mc}$, の $\mathrm{AU}^{198}$ 在注入 3 日
後であった。

2）腰部のポータブル撮影，中央部に著明なカブリ， （約180秒被曝されたものと思われる）原因，治䝤の目的 で腹腔内に $10 \mathrm{mc} \times 2$ のラジウム管挿入中。

3）胸部撮影，食道位跬にカブリ，原因，治療の日的 で, 食道部に $\mathrm{Co}^{60} 10 \mathrm{mc}$ を 1 列に 5 本地没.

4）阔上，左上肺照.

5）フィルム格納庫に積重秝てあったフィルムのカブ リ。

原因，コンクリート壁で隔した隣室（医局）からの放 射線源によるカブリ，鉄筋の陰影亡思われる 2 条の放射 条の陰影がフィルムの側方から入射している。

[結論]

ラジウムセルから発する $\gamma$ 線はX線に近似の増感率を 示す. HS 増感紙では $12 \mathrm{mr} の$ のッテ入射鼍で $0.3 の$ 濃度になる。

$\mathrm{Co}^{60}$ から発する $\mathrm{r}$ 線は被曝の条件によって増感率が 著るしく異なる。

被曝事故 5 例についてはおおよそ被曝量推定し今後の 取扳いの参考にした，他の線源について今後さらに検討 する。

\section{質問}

事故フィルムとして示された胸部写真の場合の注人 R.I の量とフィルム装置より離脱時間は.

(石川 以本)

\section{X線フィルムの静電気障害に対する湿度の影響に つ๙}

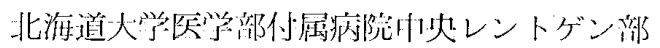

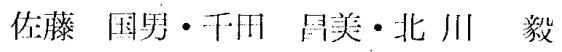

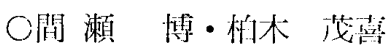

[目的〕

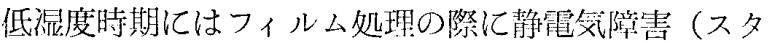

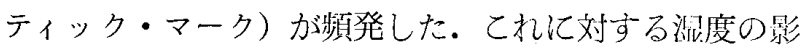
響と適正湿度について検討したので報告する。 [方法]

昭和39年 3 月より 40 年 2 月までの 1 年間に亘って当レ ントゲン部の 1 日の全フィルム処理枚数, 静電気障害発 生件数とその形状掞よび室内（暗空も含めて）湿度を記 録し，12月から4月までの低湿度期において，室内湿度 を調整した場合と調整しない場合とを比較検討した。

なお発生件数はフィルム 1 枚を 1 件として記録した。 また湿度の調整には回転躓霧式の湿潤（Humidifier）を 使用し，湿度の測定には乾湿球混度計を使用した。 [絬集] 